\title{
KCC2-Deficient Mice Show Reduced Sensitivity to Diazepam, but Normal Alcohol-Induced Motor Impairment, Gaboxadol-Induced Sedation, and Neurosteroid-Induced Hypnosis
}

\author{
Janne Tornberg', Mikael Segerstråle ${ }^{1,2}$, Natalia Kulesskaya', Vootele Voikar', Tomi Taira ${ }^{1,2}$ and \\ Matti S Airaksinen*,I \\ 'Neuroscience Center, University of Helsinki, Helsinki, Finland; '² Department of Biological and Environmental Sciences, University of Helsinki, \\ Helsinki, Finland
}

\begin{abstract}
$\mathrm{GABA}_{A}$ receptors mediate both fast phasic inhibitory postsynaptic potentials and slower tonic extrasynaptic inhibition. Hyperpolarizing phasic GABAergic inhibition requires the activity of neuron-specific chloride-extruding potassium-chloride cotransporter KCC2 in adult CNS. However, the possible role of KCC2 in tonic GABAergic inhibition and the associated behaviors is unknown. Here, we have examined the role of KCC2 in phasic vs tonic GABA inhibition by measuring the behavioral effects of pharmacological agents that presumably enhance phasic vs tonic inhibition in mice that retain 15-20\% of normal KCC2 protein levels. These KCC2-deficient mice show decreased sensitivity to diazepam-induced sedation and motor impairment consistent with the reported role for KCC2 in fast hyperpolarizing inhibition. In contrast, the mice exhibit normal responses to low-dose alcohol-induced motor impairment, gaboxadolinduced sedation, and neurosteroid-induced hypnosis; behaviors thought to be associated with tonic GABAergic inhibition. Electrophysiological recordings show that the tonic conductance is not affected. The results suggest that KCC2 activity is more critical for behaviors dependent on phasic than tonic GABAergic inhibition.

Neuropsychopharmacology (2007) 32, 91 I-918. doi: I0.1038/sj.npp. I301 195; published online I6 August 2006
\end{abstract}

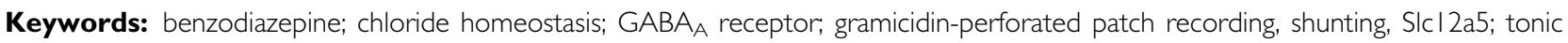
inhibition

\section{INTRODUCTION}

In adult mammalian CNS, most of the fast neurotransmitter-mediated inhibitory activity is mediated through the activation of ionotropic $\mathrm{GABA}_{\mathrm{A}}$ receptors. Neuronal inhibition mediated by $\mathrm{GABA}_{\mathrm{A}}$ receptors is essential for information processing in the CNS, and $\mathrm{GABA}_{\mathrm{A}}$ receptor dysfunction is implicated in many pathological processes such as epilepsy, pain, and anxiety (Rudolph and Mohler, 2004). Ionotropic GABAergic inhibition can be divided into two components; transient and fast, synaptic 'phasic' inhibition, and persistent, slower 'tonic' inhibition, which mainly derives from extrasynaptic $\mathrm{GABA}_{\mathrm{A}}$ receptors (Farrant and Nusser, 2005; Mody and Pearce, 2004; Semyanov et al, 2004). Importantly, synaptic and extra-

\footnotetext{
*Correspondence: Dr MS Airaksinen, Neuroscience Center, University of Helsinki, Viikinkaari 4, PO Box 56, FIN-000I4 Helsinki, Finland, Tel: + 3589 191 57650, Fax: + 3589 191 57620,

E-mail: mairaksi@operoni.helsinki.fi

Received 27 December 2005; revised 30 June 2006; accepted 13 July 2006

Online publication: 2I July 2006 at http:/www.acnp.org/citations/ Npp072106050766/default.pdf
}

synaptic $\mathrm{GABA}_{\mathrm{A}}$ receptors differ in their subunit compositions (Nusser et al, 1998) that determine whether the receptor function is enhanced by allosteric modulators, such as benzodiazepines and neurosteroids (Hevers and Luddens, 1998; Korpi and Sinkkonen, 2006; Sieghart and Speck, 2002). A classical benzodiazepine, diazepam, binds to predominantly synaptic $\mathrm{GABA}_{\mathrm{A}}$ receptor subtypes; whereas extrasynaptic receptors that mediate tonic currents in the thalamus, cerebellum and dentate granule cells are unable to bind the drug (Rudolph and Mohler, 2004). On the other hand, the extrasynaptic $\mathrm{GABA}_{\mathrm{A}}$ receptors can be selectively enhanced by neurosteroids and alcohol both in vitro (Hamann et al, 2002; Stell et al, 2003; Wallner et al, 2003; Wei et al, 2004; Wohlfarth et al, 2002; but see Borghese et al, 2006) and in vivo (Hanchar et al, 2005, 2006; Maguire et al, 2005; Mihalek et al, 1999; Wallner et al, 2006).

Activation of $\mathrm{GABA}_{\mathrm{A}}$ receptors at synapses opens an anion conductance, which typically results in both postsynaptic hyperpolarization (mediated by Cl-influx) and shunting of excitatory currents (because of increased conductance), which leads to a transient decrease in the probability of action potential initiation. The hyperpolarizing response requires an efficient chloride extrusion 
mechanism, which is achieved through the activity of the chloride-extruding potassium-chloride cotransporter KCC2 (Mercado et al, 2004; Payne et al, 2003) (also known as Slc12a5). This role of KCC2 is directly evidenced in slice cultures of hippocampal neurons in which antisense knockdown of KCC2 results in a decrease of hyperpolarizing GABA responses (Rivera et al, 1999), and in KCC2knockout mice in which the normally hyperpolarizing motoneuron GABA responses are absent (Hubner et al, 2001). Whereas synaptic inhibition may operate through both hyperpolarization and shunting, tonic inhibition probably mediates its effect predominantly through shunting mechanism (Brickley et al, 1996; Mitchell and Silver, 2003). Thus, drugs acting on phasic inhibition would be less effective when GABA is less hyperpolarizing, but that this should have no effect on the efficacy of drugs acting on tonic inhibition. To date, no experimental evidence exists concerning the role of KCC2 in the tonic form of GABAergic inhibition. We hypothesized that the shunting inhibition, which operates even if GABA is depolarizing (Staley and Mody, 1992), would remain effective in hypomorphic KCC2deficient mice (Tornberg et al, 2005). These KCC2 ${ }^{\text {hy/null }}$ mice retain $15-20 \%$ of normal KCC2 protein levels in the CNS and show various behavioral deficits (Tornberg et al, 2005).

In the present study, we have investigated the requirements for $\mathrm{KCC} 2$ in the tonic vs phasic $\mathrm{GABA}_{\mathrm{A}}$ receptormediated inhibition in the adult $\mathrm{CNS}$ in vivo. For this aim, we tested the effect of drugs that are selective for the synaptic or extrasynaptic $\mathrm{GABA}_{\mathrm{A}}$ receptors on KCC2deficient mice. The experiments are based on four important previous observations. (1) Sedative and motorimpairing effects of diazepam are due to its action on $\alpha 1$ subunit containing receptors that are low-affinity, synaptic receptors (Crestani et al, 2000). (2) The sedative effect of gaboxadol (THIP) at low concentrations is presumably mediated through extrasynaptic $\delta$-subunit containing GA$\mathrm{BA}_{\mathrm{A}}$ receptors (Brown et al, 2002; Belelli et al, 2005; Cope et al, 2005; Maguire et al, 2005). (3) The effects of low-dose alcohol on motor impairment are mediated at least in part by $\alpha 4 / \alpha 6$ - and $\delta$-subunit containing $\mathrm{GABA}_{\mathrm{A}}$ receptors that are expressed extrasynaptically and mediate tonic inhibition (Hanchar et al, 2005, 2006). (4) The effect of neurosteroids is predominantly through an action on extrasynaptic $\delta$ subunit containing $\mathrm{GABA}_{\mathrm{A}}$ receptors that mediate tonic inhibition (Mihalek et al, 1999). To simplify the interpretation, we selected behavioral tasks, in which the basal drugfree performance of KCC2-deficient mice does not differ from their wild-type (WT) littermates (Tornberg et al, 2005).

\section{MATERIALS AND METHODS}

\section{Animals}

Generation and genotyping of hypomorphic KCC2-deficient $\left(\mathrm{KCC} 2^{\text {hy/null }}\right)$ mice has been described previously (Tornberg et al, 2005). The $\mathrm{KCC} 2^{\text {hy/null }}$ mice are compound heterozygous for KCC2 null and hypomorphic alleles and retain $15-20 \%$ of normal KCC2 protein levels in the brain. In the KCC2 null allele, a neo-cassette in exon 4 of the KCC2 gene disrupts the reading frame, whereas in the KCC2 hypomorphic allele, a neo-cassette lies within intron 3 in the opposite orientation relative to the $K C C 2$ gene. $\mathrm{KCC} 22^{\text {hy/null }}$ and WT littermates in a $(\mathrm{C} 57 \mathrm{BL} / 6 \times 129 \mathrm{~S} 2) \mathrm{F}_{1}$ hybrid background were used in all the experiments described in this study. The mice were housed in standard polycarbonate cages covered with wire lid (Macrolon, Scanbur A/S, Karlsrunde, Denmark), 2-4 adult mice per cage $\left(27 \times 21 \times 14 \mathrm{~cm}^{3}\right)$, in specific pathogen-free conditions under a regular dark/light cycle (lights on 0700, off 1900 hours) with free access to standard rodent food and water.

A group of 3 - to 5-month-old littermate mice (20 WT male, $14 \mathrm{KCC} 2^{\text {hy/null }}$ male, $16 \mathrm{WT}$ female, $23 \mathrm{KCC} 2$ hy/null female mice) was subjected to behavioral testing. As behavioral testing revealed no differences between the sexes, the results were pooled. An additional cohort of 2-month-old littermate ( $21 \mathrm{WT}$ and $\left.19 \mathrm{KCC} 2^{\text {hy/null }}\right)$ mice was used for testing the effect of gaboxadol. All animal experiments were approved by the ethics committee for animal research at the University of Helsinki.

\section{Open Field}

The effect of diazepam (Stesolid Novum, Dumex-Alpharma A/S, Copenhagen, Denmark) and gaboxadol hydrocloride (4,5,6,7-tetrahydroisoxazolo[5,4-c]pyridine-3-ol; THIP, Sigma-Aldrich) on spontaneous locomotor activity was measured in the automated open field $\left(30 \times 30 \mathrm{~cm}^{2}\right.$; MedAssociates, VT) for $30 \mathrm{~min}$. The mice, unfamiliar with the testing environment, were administered intraperitoneally (i.p.) with diazepam $(2 \mathrm{mg} / \mathrm{kg})$, gaboxadol $(10 \mathrm{mg} / \mathrm{kg})$ or vehicle $(0.9 \% \mathrm{NaCl}) 30 \mathrm{~min}$ before the testing.

\section{Accelerating Rotarod}

The mice were trained on an accelerating rotarod (Ugo Basile, Comerio, Italy) equipped with automatic fall detector in six trials on 3 succeeding days (two trials a day). The speed of rotation increased at a constant rate (from 3 to 30 r.p.m.) over $5 \mathrm{~min}$ and cutoff time was $6 \mathrm{~min}$. The first three trials showed no difference between the genotypes, consistent with our previous study reporting normal motor coordination in the KCC2 mutants (Tornberg et al, 2005). However, the $\mathrm{KCC} 2^{\text {hy/null }}$ mice displayed a slight deficit during the subsequent learning trials (data not shown), suggesting that the KCC2 $2^{\text {hy/null }}$ mice may exhibit a mild deficit in motor learning (but not in motor coordination per se). Mice that failed to stay on the rod for $120 \mathrm{~s}$ on the pretrial test were excluded from the experiment (three WT and six KCC2 $2^{\text {hy/null }}$ mice).

After the learning trials, the animals were used in ethanol and diazepam experiments with at least 5 days and one injection-free trial on rotarod in-between the drug injections. The tested dose of ethanol (Primalco, Rajamäki, Finland; $12 \%$ weight/volume, diluted in $0.9 \% \mathrm{NaCl}$ ) was $1.25 \mathrm{~g} / \mathrm{kg}$ (i.p.). The performance was measured as the latency to fall from the rotating rod before (pretrial) and 10 and $40 \mathrm{~min}$ after the ethanol injection. Similarly, the effect of diazepam (3 or $10 \mathrm{mg} / \mathrm{kg}$, i.p.) on rotarod performance was tested before and 30 and $60 \mathrm{~min}$ after the drug injection.

\section{Loss of Righting Reflex (LORR)}

Mice were tested for the duration of the loss of the righting reflex ('sleep time') in response to the neuroactive steroid, 
pregnanolone (5 $\beta$-pregnan-3 $\alpha$-ol-20-one; Sigma-Aldrich, $8 \mathrm{mg} / \mathrm{kg}$ ) as described previously (Mihalek et al, 1999). The drug was dissolved in a $22.5 \%$ (wt/vol) solution of 2-hydroxypropyl- $\beta$-cyclodextrin (Sigma-Aldrich). Upon the intravenous injection of the drug, the mice became immobile in $5 \mathrm{~s}$ and were placed on their backs in a v-shaped trough. Mice were monitored until they could right themselves three times in $30 \mathrm{~s}$, and the time to pass the criteria was recorded. A heat lamp was used to ensure normothermia.

\section{Electrophysiology}

Acute hippocampal slices were prepared from anesthetized WT and KCC2 $2^{\text {hy/null }}$ mice (16-20-day-old), using standard methods. Briefly, the brain was quickly dissected into icecold solution containing the following (in $\mathrm{mM}$ ): $124 \mathrm{NaCl}$, $3 \mathrm{KCl}, 1.25 \mathrm{NaH}_{2} \mathrm{PO}_{4}, 10 \mathrm{MgSO}_{4}, 26 \mathrm{NaHCO}_{3}, 10-15$ D-glucose, and $1 \mathrm{CaCl}_{2}$ (bubbled with $5 \% \mathrm{CO}_{2} / 95 \% \mathrm{O}_{2}$ ). A tissue block containing the hippocampi was dissected and glued into the stage of a vibratome (Vibratome, St Louis, MO). Slices ( $350 \mu \mathrm{m}$ thick) were cut sagittally in the above solution and stored at room temperature in a solution containing the following (in $\mathrm{mM}$ ): $124 \mathrm{NaCl}, 3 \mathrm{KCl}, 1.25$ $\mathrm{NaH}_{2} \mathrm{PO}_{4}, 4 \mathrm{MgSO}_{4}, 26 \mathrm{NaHCO}_{3}, 10-15$ D-glucose, and 2 $\mathrm{CaCl}_{2}\left(5 \% \mathrm{CO}_{2} / 95 \% \mathrm{O}_{2}\right)$. The slices were used $1-4 \mathrm{~h}$ after cutting.

For electrophysiological recordings, the slices were placed in a submerged recording chamber and perfused with extracellular solution containing the following (in $\mathrm{mM}$ ): 124 $\mathrm{NaCl}, 3 \mathrm{KCl}, 1.25 \mathrm{NaH}_{2} \mathrm{PO}_{4}, 1 \mathrm{MgSO}_{4}, 26 \mathrm{NaHCO}_{3}, 10-15$ D-glucose, and $2 \mathrm{CaCl}_{2}$ (bubbled with $5 \% \mathrm{CO}_{2} / 95 \% \mathrm{O}_{2}$ at $32^{\circ} \mathrm{C}$ ). Whole-cell recordings were made from visually identified CA3 interneurons, with patch electrodes (3-5 M $\Omega$ ) filled with a solution containing the following (in $\mathrm{mM}$ ): $120 \mathrm{CsCl}, 10 \mathrm{HEPES}, 0.5$ EGTA, $4 \mathrm{Mg}$-ATP, 0.3 $\mathrm{Na}-\mathrm{GTP}$, and $8 \mathrm{NaCl}$ (285 mosM), pH 7.2. Perforated patch clamp recordings were made with high resistance electrodes (12-14 M $\Omega$ ) to prevent spontaneous rupture of the gigaseal. The tip of the electrodes were filled with a solution containing the following (in $\mathrm{mM}$ ): $135 \mathrm{~K}$-gluconate, 10 HEPES, 5 EGTA, $4 \mathrm{Mg}$-ATP, $0.5 \mathrm{Na}-\mathrm{GTP}, 2 \mathrm{KCl}$, and 2 $\mathrm{Ca}(\mathrm{OH})_{2}, 290$ mosM, pH 7.2; and then backfilled with the same solution containing gramicidin $(100 \mu \mathrm{g} / \mathrm{ml}$, Sigma). Recordings were started when access resistance lower than $150 \mathrm{M} \Omega$ was reached.

The experiments were made in voltage-clamp mode, where the membrane was clamped to $-80 \mathrm{mV}$. In the breakin whole-cell experiments, the pipette solution contained a high concentration of cesium chloride, so that $\mathrm{GABA}_{\mathrm{A}}$ receptor-mediated currents at $-80 \mathrm{mV}$ were inward. In the perforated patch experiments, gramicidin was used to get a stable access to the cell. Access and input resistances were monitored throughout the experiments using a $5 \mathrm{mV}$ voltage step. AMPA/kainate, NMDA, and $\mathrm{GABA}_{\mathrm{B}}$ receptors were routinely blocked with NBQX $(50 \mu \mathrm{M})$, AP5 $(50 \mu \mathrm{M})$, and CGP52432 $(5 \mu \mathrm{M})$, respectively. The tonic $\mathrm{GABA}_{\mathrm{A}}$ receptor-mediated current was calculated as the change in baseline holding current produced by blocking $\mathrm{GABA}_{\mathrm{A}}$ receptors with picrotoxin (PiTX, $100 \mu \mathrm{M})$. Currents were acquired with a multiclamp 700A amplifier (Axon Instruments, Foster City, CA). Recordings were filtered at $2 \mathrm{kHz}$ and sampled at $4 \mathrm{kHz}$. Access and input resistances were monitored throughout the experiments using a $5 \mathrm{mV}$ voltage step.

\section{RESULTS}

\section{KCC $2^{\text {hy/null }}$ Mice are Insensitive to Diazepam-Induced Sedation}

The diazepam-induced depression of motor activity, a measure of sedation, was tested in the open field. The spontaneous locomotor activity of the vehicle-treated animals did not differ between the genotypes (Figure 1a), consistent with our previous results of similar open field performance of noninjected KCC $2^{\text {hy/null }}$ and WT littermate mice (Tornberg et al, 2005). Treating the mice with diazepam $(2 \mathrm{mg} / \mathrm{kg}$, i.p.), however, induced a significant difference in the motor activity between the genotypes (Figure 1a; effect of genotype: $\mathrm{F}_{1,69}=4.77, p<0.05$; effect of treatment: $\left.\mathrm{F}_{1,69}=8.18, p<0.01\right)$. The KCC $2^{\text {hy/null }}$ mice were
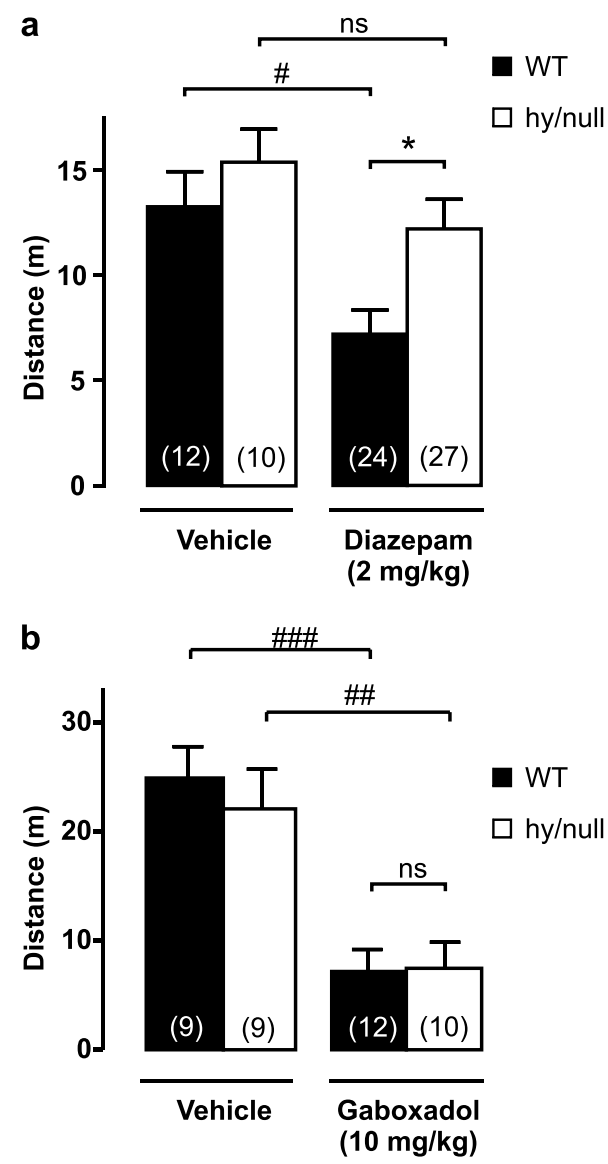

Figure I Effect of diazepam and gaboxadol in WT and $\mathrm{KCC} 2^{\text {hy/null }}$ mice on total distance traveled during a 30-min trial in open field. (a) Diazepam ( $2 \mathrm{mg} / \mathrm{kg}$, i.p.) significantly depressed the spontaneous locomotor activity in WT mice compared to vehicle-treated controls. The $\mathrm{KCC}^{\text {hy/null }}$ mice showed insensitivity to diazepam-induced sedation and were less sedated compared to the WT littermate controls. (b) In contrast, gaboxadol (THIP, $10 \mathrm{mg} / \mathrm{kg}$, i.p.) impaired the locomotor activity similarly in both WT and KCC $2^{\text {hy }}{ }_{\text {null }}$ mice. Data represent the mean $\pm S E M$. Number of mice in each group is shown in parenthesis. $* p<0.05$ between the genotypes and $\#_{p}<0.05, \# \#<0.01$, and ${ }^{\# \#} p<0.001$ within the genotype by two-way ANOVA followed by Newman-Keuls post hoc test. 
insensitive to diazepam-induced sedative effects, whereas WT mice became clearly less active by the treatment (Figure 1a; WT-vehicle vs WT-diazepam, $p<0.05$; WTdiazepam $v s$ hy/null-diazepam, $p<0.05)$.

\section{KCC2 ${ }^{\text {hy/null }}$ Mice Show Normal Gaboxadol-Induced Sedation}

The sedative effect of low-dose gaboxadol (THIP) was tested in the open field using a new cohort of mice. In contrast to diazepam, gaboxadol $(10 \mathrm{mg} / \mathrm{kg}$, i.p.) impaired the locomotor activity similarly between the genotypes (Figure $1 \mathrm{~b}$; effect of genotype: $\mathrm{F}_{1,20}=0.01, p=0.92$; effect of treatment for WT: $\mathrm{F}_{1,19}=25.18, p<0.001$, for KCC2 ${ }^{\text {hy/null }}: \mathrm{F}_{1,17}=11.66 p<0.003$ ).

\section{KCC2 ${ }^{\text {hy/null }}$ Mice Show Normal Alcohol-Induced Motor} Coordination Impairment

The motor impairing effect of low dose of ethanol was assessed in the accelerating rotarod. The mice were first trained to stay on the rod on 3 consecutive days (two trials per day until no significant improvement took place). Next day following the last learning trial, the mice were tested on the rotarod before (pretrial) and 10 and $40 \mathrm{~min}$ after the ethanol $(1.25 \mathrm{~g} / \mathrm{kg}$ body weight, i.p.) injection. The $\mathrm{KCC}^{\text {hy/null }}$ mice showed no motor impairment in the pretrial test compared to WT control mice (Figure 2a). Post hoc analysis detected a significant reduction in motor abilities measured $10 \mathrm{~min}$ after the ethanol injection in both genotypes (Figure 2a; WT $p<0.001$; hy/null $p<0.001$ ). Although the $\mathrm{KCC} 2^{\text {hy/null }}$ mice showed slightly decreased alcohol sensitivity, the difference was not significant between the genotypes (Figure 2a; effect of genotype: $\mathrm{F}_{1,45}=0.104, p=0.75$; interaction of genotype and trial: $\mathrm{F}_{2,90}=1.67, p=0.19$ ).

\section{KCC2 ${ }^{\text {hy/null }}$ Mice are Less Sensitive to Diazepam-Induced} Motor Coordination Impairment

Five days after the alcohol test, the mice were assessed for the motor coordination impairing effects of diazepam. The mice were tested in the accelerating rotarod before (pretrial) and after (30 and $60 \mathrm{~min})$ the drug injection. The pretrial test showed no difference in the motor abilities between the genotypes (Figure $2 \mathrm{~b}$ ), consistent with the alcohol pretrial test. Diazepam (3 mg/kg, i.p.) treatment revealed a significant difference between the genotypes (Figure $2 b$; effect of genotype: $\mathrm{F}_{1,45}=17.71, p<0.001$; interaction of genotype and trial: $\left.\mathrm{F}_{2,90}=12.49, p<0.001\right)$. Post hoc test revealed a reduction in motor abilities in both genotypes measured $30 \mathrm{~min}$ after the drug injection (Figure 2b; WT $p<0.001$; hy/null $p<0.01)$. However, the KCC2 ${ }^{\text {hy/null }}$ mice performed the task significantly better than WT controls $(p<0.001$ measured at 30 and $60 \mathrm{~min}$ after the injection). Higher, clearly sedative dose of diazepam $(10 \mathrm{mg} / \mathrm{kg})$ severely impaired motor coordination in both genotypes (Figure 2c).

\section{KCC2 ${ }^{\text {hy/null }}$ Mice Show Normal Neurosteroid-Induced Hypnotic Effects}

The LORR assay was conducted to determine whether the hypnotic effects of neuroactive steroid pregnanolone were a

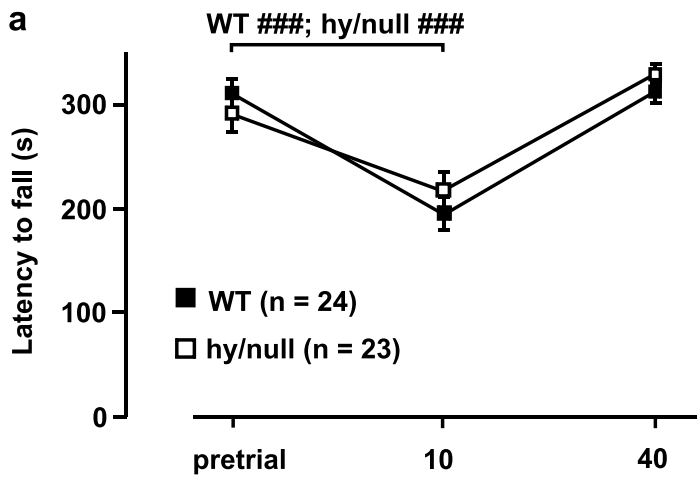

Time after ethanol injection (min)

b

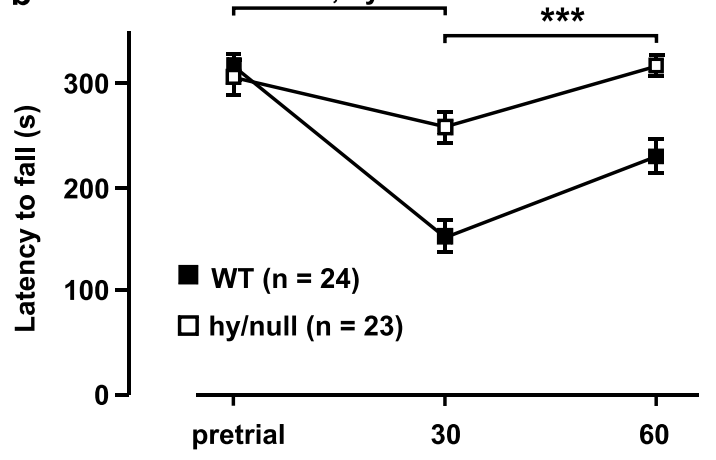

Time after diazepam $(3 \mathrm{mg} / \mathrm{kg})$ injection $(\min )$

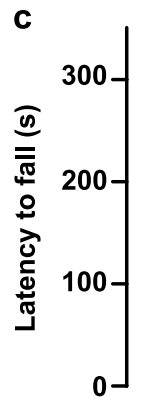

WT \#\#; hy/null \#\#\#
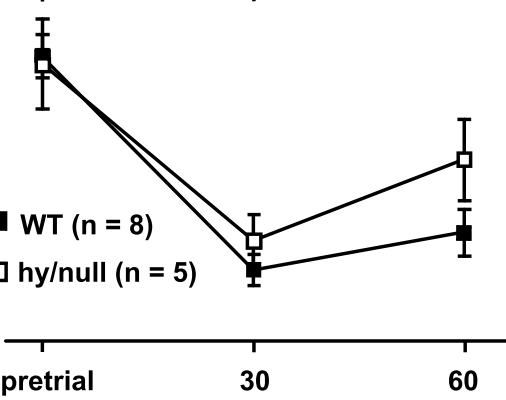

Time after diazepam $(10 \mathrm{mg} / \mathrm{kg})$ injection ( $\mathrm{min})$

Figure 2 Effect of alcohol (1.25 g/ $/ \mathrm{kg}$, i.p.) and diazepam (3 or $10 \mathrm{mg} / \mathrm{kg}$ i.p.) on rotarod performance in WT and KCC2 ${ }^{\text {hy/null }}$ mice. (a) Low dose of ethanol reduced the motor abilities of both genotypes measured $10 \mathrm{~min}$ after the injection. The ethanol-induced motor impairment showed no difference between the WT and KCC2 ${ }^{\text {hy/null }}$ mice measured at two postinjection data points ( 10 and $40 \mathrm{~min}$ after the ethanol injection). (b) Low dose $(3 \mathrm{mg} / \mathrm{kg})$ diazepam-treatment impaired the motor coordination in both genotypes measured $30 \mathrm{~min}$ after the injection. The effect of diazepam was, however, significantly weaker in $\mathrm{KCC} 2^{\text {hy/null }}$ mice compared to WT controls measured at the two postinjection data points. (c) Higher, clearly sedative dose of diazepam $(10 \mathrm{mg} / \mathrm{kg})$ severely impaired motor coordination in both genotypes. Data represent mean \pm SEM. **** $p<0.00$ I between the genotypes; ${ }^{\# \#} p<0.01$ and ${ }^{\# \#} p<0.001$ within the genotype by repeated measures ANOVA followed by Newman-Keuls post hoc test.

altered in the KCC2 mutant mice. The pregnanoloneinduced $(8 \mathrm{mg} / \mathrm{kg}$, intravenous (i.v.)) duration of LORR did not differ between the WT and KCC2 $2^{\text {hy/null }}$ mice (Figure 3; $p=0.9$ using the $t$-test). 
Tonic Current in KCC2 ${ }^{\text {hy/null }}$ Neurons is Normal Using Whole-Cell but Changed Using Gramicidin-Perforated Patch Recordings

When tonic GABAergic current was measured in hippocampal interneurons by conventional whole-cell-clamp technique (Figure 4a), PiTX caused a similar shift in the holding current between the genotypes (WT $41 \pm 4 \mathrm{pA}$, $n=7$; hy/null $45 \pm 6 \mathrm{pA}, n=4$ ), indicating that the tonic conductance was the same. However, in the perforated patch-clamp experiments (Figure $4 \mathrm{~b}$ ), the tonic current (PiTX-sensitive holding current) corrected for cell capacitance (Scimemi et al, 2005), was lower in WT than in KCC2 $2^{\text {hy/null }}$ neurons when clamped at $-80 \mathrm{mV}$ (WT $320 \pm$ $70 \mathrm{pA} / \mathrm{nF}, n=4$; hy/null $560 \pm 30 \mathrm{pA} / \mathrm{nF}, n=3 ; p=0.03)$.

\section{DISCUSSION}

In this study, we show that the $\mathrm{KCC} 2^{\text {hy/null }}$ mice display impaired responses to diazepam-induced sedation and motor impairment, but normal responses to alcoholinduced motor impairment, gaboxadol-induced sedation, and neurosteroid-induced hypnosis. These results are consistent with the reported role for KCC2 in the hyperpolarizing synaptic inhibition and indicate that a

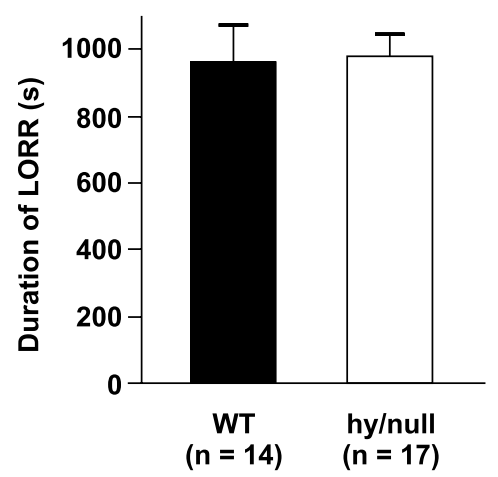

Figure 3 Duration of LORR induced by pregnanolone $(8 \mathrm{mg} / \mathrm{kg}$, i.v. $)$ in WT and KCC2 ${ }^{\text {hy/null }}$ mice. The duration of LORR was similar between the genotypes. Data represent mean \pm SEM. profound (80-85\%) deficiency of normal KCC2 levels (and thus Cl-extrusion capacity) in adult CNS does not affect the correct functioning of tonic GABAergic inhibition at the behavioral level. This suggests that KCC2 is predominantly involved in the phasic but not in the tonic component of GABAergic neurotransmission.

The synaptic $\mathrm{GABA}_{\mathrm{A}}$ receptor activation results typically in hyperpolarizing inhibitory postsynaptic potentials, which are dependent on the chloride extruding activity of KCC2 (Hubner et al, 2001; Rivera et al, 1999; Woo et al, 2002; Zhu et al, 2005). Although the synaptic (phasic) inhibition also includes a shunting component, extrasynaptic (tonic and presynaptic) inhibition is thought to operate mainly via the shunting mechanism (through the opening of the $\mathrm{GABA}_{\mathrm{A}}$ receptor channel causing a decrease in membrane resistivity), which is effective even if GABA is depolarizing (Staley and Mody, 1992). We have previously reported several behavioral phenotypes of the hypomorphic KCC2-deficient mice (Tornberg et al, 2005), including increased anxiety and seizure susceptibility, poor spatial learning and memory, hyposensitivity to thermal and mechanical stimuli, and reduced weigh but apparently normal locomotor activity and motor coordination. Interestingly, the mice showed normal anticonvulsant responses to an anesthetic drug, propofol, which preferentially enhances the tonic $\mathrm{GABA}_{\mathrm{A}}$ receptor-mediated conductances in hippocampal neurons (Bai et al, 2001; Bieda and MacIver, 2004), suggesting that the tonic inhibition would remain effective in KCC2 mutant mice.

Mice with a point mutation in the $\mathrm{GABA}_{\mathrm{A}}$ receptor $\alpha 1$ subunit are insensitive to low-dose diazepam-induced sedation and motor impairment (Crestani et al, 2000; McKernan et al, 2000; Rudolph et al, 1999), implying that these diazepam effects are mediated through the activation of receptors that contain $\alpha 1$ subunit, which are predominantly expressed postsynaptically (Farrant and Nusser, 2005). Thus, to specifically examine the role of KCC2 in the phasic (synaptic) form of GABAergic inhibition, we tested the locomotor-impairing/sedative effect of diazepam in the $\mathrm{KCC} 2^{\text {hy/null }}$ mice in open field. A dose of diazepam $(2 \mathrm{mg} / \mathrm{kg}$, i.p.) that markedly depressed the motor activity (distance traveled) in the WT mice resulted in only a slight
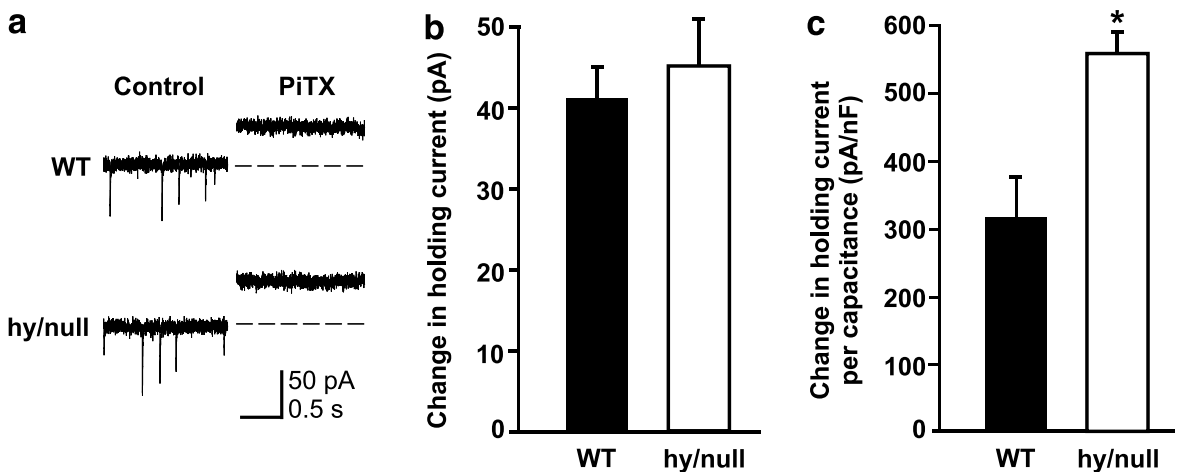

Figure 4 Effect of PiTX on holding current in CA3 stratum lucidum interneurons in WT and KCC2 ${ }^{\text {hy/null }}$ mice. (a) Representative traces obtained in whole-cell mode from one WT and one KCC2 ${ }^{\text {hy/null }}$ interneuron. PiTX abolished spontaneous IPSCs and decreased the holding current. (b) In whole-cell experiments, PiTX shifted the holding current similarly in WT and KCC2 ${ }^{\text {hy/null }}$ neurons. (c) In gramicidin-perforated patch experiments, tonic current density, measured as the ratio of PiTX-sensitive holding current to cell capacitance, was lower in WT than in KCC2 ${ }^{\text {hy/null }}$ neurons. The membrane potential was clamped to $-80 \mathrm{mV}$ in both experiments. Experiments were performed in the presence of glutamate receptor and GABA $A_{B}$ receptor antagonists. Data represent mean \pm SEM. $* p=0.03$ using the $t$-test. 
decrease in spontaneous motor activity in the $\mathrm{KCC} 22^{\text {hy/null }}$ mice. This resistance to diazepam-induced sedation is consistent with compromised synaptic inhibition in the KCC2-deficient mice. In contrast to diazepam, low dose of gaboxadol impaired locomotor activity in the open field test similarly between the genotypes. As gaboxadol is thought to specifically target extrasynaptic GABA receptors (eg Belelli et al 2005), this result suggests that tonic GABA inhibition may be relatively intact in the KCC2-deficient mice.

A naturally occurring point mutation in $\mathrm{GABA}_{\mathrm{A}}$ receptor subunit $\alpha 6$ is reported to render rats more sensitive to lowdose $(1.25 \mathrm{~g} / \mathrm{kg})$ alcohol-induced motor impairment by selectively increasing the alcohol sensitivity of a specific extrasynaptic $\mathrm{GABA}_{\mathrm{A}}$ receptor subtype, $\alpha 6 \beta 3 \delta$, which is exclusively expressed in cerebellar granule cells, suggesting that alcohol impairs motor coordination by enhancing granule cell tonic inhibition (Hanchar et al, 2005). Although the mechanism by which ethanol modulates tonic GABAergic inhibition in cerebellar granule neurons is still a matter of debate (Borghese et al, 2006), recent studies provide further evidence that behavioral low-dose ethanol effects are to a large extent mediated by extrasynaptic $\mathrm{GABA}_{\mathrm{A}}$ receptors (Hanchar et al, 2006; Wallner et al, 2006). To investigate the effects of KCC2 alterations in this model of tonic inhibition, we tested the $\mathrm{KCC} 2^{\text {hy/null }}$ mice in accelerating rotarod before and after the low dose of alcohol-treatment. Importantly, motor abilities were similar between the genotypes in the pretrial test and were significantly impaired after alcohol administration similarly in both genotypes. This result is consistent with a recent report showing that almost all GABAergic inhibition in cerebellar slices from adult rats is mediated by extrasynaptic currents, which are not affected by blocking $(\sim 80 \%)$ of $\mathrm{KCl}$ cotransport (Hamann et al, 2002). As the cerebellar information processing is profoundly modulated by GABAergic shunting inhibition (Mitchell and Silver, 2003; Chadderton et al, 2004), these results imply the integrity of tonic GABAergic inhibition in the cerebellum of KCC2deficient mice.

To further compare the effect of phasic $v s$ tonic enhancement of GABAergic inhibition in the $\mathrm{KCC} 2^{\text {hy/null }}$ mice in the same behavioral task, we repeated the accelerating rotarod test by replacing ethanol with diazepam. Again, the pretrial test showed no differences in the motor abilities between the genotypes. The enhancement of phasic GABAergic inhibition by diazepam, however, revealed a significant difference between the WT and $\mathrm{KCC} 2^{\text {hy/null }}$ mice rotarod performance. Diazepam at $3 \mathrm{mg} / \mathrm{kg}$ (i.p.) significantly impaired the motor abilities in both genotypes, but the effect was considerably stronger in the WT mice. This is consistent with the open field results and shows that the phasic GABAergic inhibition mediated by the $\alpha 1$ subunit containing $\mathrm{GABA}_{\mathrm{A}}$ receptors is impaired in the $\mathrm{KCC} 2{ }^{\text {hy/null }}$ mice. The difference between genotypes was smaller using higher dose of diazepam $(10 \mathrm{mg} / \mathrm{kg}$, i.p.) that causes more severe sedation and impairment of rotarod performance. This is consistent with previous results that sedative/motor impairing effects of higher dose of diazepam are mediated also via other than synaptic $\alpha 1$ subunit containing $\mathrm{GABA}_{\mathrm{A}}$ receptors (eg Crestani et al, 2000).

The tonic form of GABAergic inhibition is also highly sensitive and selectively enhanced by neuroactive steroids acting through $\delta$ subunit containing $\mathrm{GABA}_{\mathrm{A}}$ receptors (Stell et al, 2003; Wohlfarth et al, 2002). This has been assessed at the behavioral level by $\delta$ subunit-knockout mice that show a reduced sleep time induced by neuroactive steroid pregnanolone (Mihalek et al, 1999). Consistent with the gaboxadolinduced sedation and alcohol-induced motor impairment, pregnanolone-induced LORR showed no difference in duration between WT and KCC2 $2^{\text {hy/null }}$ mice. This further supports our conclusion that a profound reduction of KCC2 levels in the adult CNS has little if any effect on tonic GABA signaling at the behavioral level.

Consistent with previous reports that KCC2 is the predominant $\mathrm{Cl}^{-}$extrusion mechanism in adult neurons (Hubner et al, 2001; Rivera et al, 1999; Woo et al, 2002; Zhu et al, 2005), hippocampal pyramidal neurons from the $\mathrm{KCC} 2^{\text {hy/null }}$ mice show a marked positive shift in the reversal potential for $\mathrm{GABA}\left(E_{\mathrm{GABA}}\right.$, WT: $-69 \pm 4 \mathrm{mV}, n=6$, hy/null: $-48 \pm 5 \mathrm{mV}, n=5$ ) (R Riekki et al, Unpublished data). Consequently, the increase in intracellular $\mathrm{Cl}^{-}$in $\mathrm{KCC} 2^{\text {hy/null }}$ neurons moves the GABA reversal potential to more positive values, and in some neurons this may even lead to a switch in the polarity of the $\mathrm{GABA}_{\mathrm{A}}$ receptormediated responses from hyperpolarizing to depolarizing; a finding consistent with the observed reduction in diazepam sensitivity in the KCC2 mutant mice. As diazepam remains inhibitory in the mice, particularly at the higher $(10 \mathrm{mg} / \mathrm{kg})$ dose, either most neurons do not switch the polarity of $\mathrm{GABA}_{\mathrm{A}}$ receptor-mediated responses or that the shunting component of synaptic receptors plays an important role in the inhibitory actions of classical benzodiazepines.

When tonic GABAergic current was measured in hippocampal interneurons by conventional whole-cell-clamp technique, no change in holding current was observed between the genotypes. This indicates that tonic $\mathrm{GABA}_{\mathrm{A}}$ conductance, receptor expression, and extracellular GABA levels are comparable between the genotypes and that no adaptive plasticity in the $\mathrm{GABA}_{\mathrm{A}}$ receptors mediating the tonic current had taken place (Scimemi et al, 2005). However, when measured using the gramicidinperforated patch-clamp configuration that maintains internal $\mathrm{Cl}^{-}$homeostasis, tonic current density (change in holding current per cell capacitance) was higher in the KCC2 ${ }^{\text {hy/null }}$ neurons when the cells were held at $-80 \mathrm{mV}$. This indicates a more positive $E_{\mathrm{GABA}}$ of the tonic current in these animals that is consistent with the positive shift in $E_{\mathrm{GABA}}$ in synaptically induced $\mathrm{GABA}_{\mathrm{A}}$ receptor-mediated responses. However, as the physiological role of the tonic GABAergic transmission is to maintain inhibitory background tone in the neuronal network via shunting (Semyanov et al, 2004), the positive shift in the $E_{\mathrm{GABA}}$ does not necessarily compromise this.

In contrast to hyperpolarizing inhibition, shunting inhibition is nonlinear phenomenon behaving in an onoff like manner (Koch et al, 1983) and is efficient even if GABA is depolarizing (Staley and Mody, 1992). The key element in shunting inhibition is the increase in membrane conductance, which limits depolarization above $E_{\mathrm{GABA}}$ and therefore inhibits the membrane potential from reaching an action potential threshold, provided that the $E_{\mathrm{GABA}}$ is below this value (Owens and Kriegstein, 2002). We propose that the functional outcome of tonic GABA inhibition assessed at the behavioral level remains intact, because $E_{\mathrm{GABA}}$ still 
remains hyperpolarized relative to action potential threshold so that the tonic current can still effectively diminish excitatory inputs. However, it remains possible that under certain conditions (such as during prolonged hyperexcitability) that lead to accumulation of intracellular chloride levels, the altered tonic current (due to reduced chloride extrusion capacity) in $\mathrm{KCC} 2^{\text {hy/null }}$ mice could manifest at the behavioral level, such as increased seizure susceptibility (Maguire et al, 2005).

In summary, the role of KCC2 in hyperpolarizing GABA responses (shifting the $E_{\mathrm{GABA}}$ toward more negative potentials) is emphasized in phasic GABA inhibition. We show here that weakened hyperpolarizing GABA responses due to KCC2 deficiency are directly correlated in the animal behavior, whereas changed tonic GABA current does not necessarily manifest in behavior. This suggests that, at least under most physiological conditions, $15-20 \%$ of KCC2 is sufficient to maintain the $E_{\mathrm{GABA}}$ in the shunting range of $\mathrm{GABA}_{\mathrm{A}}$ receptor activation and thus preserve the correct functional outcome of tonic GABAergic neurotransmission.

\section{ACKNOWLEDGEMENTS}

This work was supported by grants from the Finnish Academy and the Sigrid Jusélius Foundation. We thank Kaija Berg for technical assistance and the three anonymous reviewers for their constructive comments.

\section{REFERENCES}

Bai D, Zhu G, Pennefather P, Jackson MF, MacDonald JF, Orser BA (2001). Distinct functional and pharmacological properties of tonic and quantal inhibitory postsynaptic currents mediated by gamma-aminobutyric acid(A) receptors in hippocampal neurons. Mol Pharmacol 59: 814-824.

Belelli D, Peden DR, Rosahl TW, Wafford KA, Lambert JJ (2005). Extrasynaptic GABAA receptors of thalamocortical neurons: a molecular target for hypnotics. J Neurosci 25: 11513-11520.

Bieda MC, MacIver MB (2004). Major role for tonic GABAA conductances in anesthetic suppression of intrinsic neuronal excitability. J Neurophysiol 92: 1658-1667.

Borghese CM, Storustovu SI, Ebert B, Herd MB, Belelli D, Lambert JJ et al (2006). The delta subunit of $\gamma$-aminobutyric acid type A receptors does not confer sensitivity to low concentrations of ethanol. J Pharmacol Exp Ther 316: 1360-1368.

Brickley SG, Cull-Candy SG, Farrant M (1996). Development of a tonic form of synaptic inhibition in rat cerebellar granule cells resulting from persistent activation of GABAA receptors. J Physiol London 497: 753-759.

Brown N, Kerby J, Bonnert TP, Whiting PJ, Wafford KA (2002). Pharmacological characterization of a novel cell line expressing human alpha(4)beta(3)delta GABA(A) receptors. Br J Pharmacol 136: 965-974.

Cope DW, Hughes SW, Crunelli V (2005). GABAA receptormediated tonic inhibition in thalamic neurons. J Neurosci 25: 11553-11563.

Chadderton P, Margrie TW, Hausser M (2004). Integration of quanta in cerebellar granule cells during sensory processing. Nature 428: 856-860.

Crestani F, Martin JR, Mohler H, Rudolph U (2000). Resolving differences in GABAA receptor mutant mouse studies. Nat Neurosci 3: 1059-1059.

Farrant M, Nusser Z (2005). Variations on an inhibitory theme: phasic and tonic activation of GABA(A) receptors. Nat Rev Neurosci 6: 215-229.
Hamann M, Rossi DJ, Attwell D (2002). Tonic and spillover inhibition of granule cells control information flow through cerebellar cortex. Neuron 33: 625-633.

Hanchar HJ, Dodson PD, Olsen RW, Otis TS, Wallner M (2005). Alcohol-induced motor impairment caused by increased extrasynaptic GABA(A) receptor activity. Nat Neurosci 8: 339-345.

Hanchar HJ, Chutsrinopkun P, Meera P, Supavilai P, Sieghart W, Wallner $M$ et al (2006). Ethanol potently and competitively inhibits binding of the alcohol antagonist Ro15-4513 to $\alpha 4 / 6 \beta 3 \delta$ GABAA receptors. Proc Natl Acad Sci USA 103: 8546-8551.

Hevers W, Luddens H (1998). The diversity of GABA(A) receptors - pharmacological and electrophysiological properties of GABA(A) channel subtypes. Mol Neurobiol 18: 35-86.

Hubner CA, Stein V, Hermans-Borgmeyer I, Meyer T, Ballanyi K, Jentsch TJ (2001). Disruption of KCC2 reveals an essential role of $\mathrm{K}-\mathrm{Cl}$ cotransport already in early synaptic inhibition. Neuron 30: $515-524$.

Koch C, Poggio T, Torre V (1983). Nonlinear interactions in a dendritic tree: localization, timing, and role in information processing. Proc Natl Acad Sci USA 80: 2799-2802.

Korpi ER, Sinkkonen ST (2006). GABA $_{A}$ receptor subtypes as targets for neuropsychiatric drug development. Pharmacol Ther 109: 12-32.

Maguire JL, Stell BM, Rafizadeh M, Mody I (2005). Ovarian cyclelinked changes in $\mathrm{GABA}(\mathrm{A})$ receptors mediating tonic inhibition alter seizure susceptibility and anxiety. Nat Neurosci 8: 797-804.

McKernan RM, Rosahl TW, Reynolds DS, Sur C, Wafford KA, Atack JR et al (2000). Sedative but not anxiolytic properties of benzodiazepines are mediated by the GABAA receptor (alpha)1 subtype. Nat Neurosci 3: 587-592.

Mercado A, Mount DB, Gamba G (2004). Electroneutral cationchloride cotransporters in the central nervous system. Neurochem Res 29: 17-25.

Mihalek RM, Banerjee PK, Korpi ER, Quinlan JJ, Firestone LL, Mi $\mathrm{ZP}$ et al (1999). Attenuated sensitivity to neuroactive steroids in gamma-aminobutyrate type A receptor delta subunit knockout mice. Proc Natl Acad Sci USA 96: 12905-12910.

Mitchell SJ, Silver RA (2003). Shunting inhibition modulates neuronal gain during synaptic excitation. Neuron 38: 433-445.

Mody I, Pearce RA (2004). Diversity of inhibitory neurotransmission through GABAA receptors. Trends Neurosci 27: 569-575.

Nusser Z, Sieghart W, Somogyi P (1998). Segregation of different GABAA receptors to synaptic and extrasynaptic membranes of cerebellar granule cells. J Neurosci 18: 1693-1703.

Owens DF, Kriegstein AR (2002). Is there more to GABA than synaptic inhibition? Nat Rev Neurosci 3: 715-727.

Payne JA, Rivera C, Voipio J, Kaila K (2003). Cation-chloride co-transporters in neuronal communication, development and trauma. Trends Neurosci 26: 199-206.

Rivera C, Voipio J, Payne JA, Ruusuvuori E, Lahtinen H, Lamsa K et al (1999). The $\mathrm{K}+/ \mathrm{Cl}^{-}$co-transporter $\mathrm{KCC} 2$ renders GABA hyperpolarizing during neuronal maturation. Nature 397: 251-255.

Rudolph U, Mohler H (2004). Analysis of GABAA receptor function and dissection of the pharmacology of benzodiazepines and general anesthetics through mouse genetics. Annu Rev Pharmacol Toxicol 44: 475-498.

Rudolph U, Crestani F, Benke D, Brunig I, Benson JA, Fritschy JM et al (1999). Benzodiazepine actions mediated by specific $\gamma$-aminobutyric acid A receptor subtypes. Nature 401: 796-800.

Scimemi A, Semyanov A, Sperk G, Kullmann DM, Walker MC (2005). Multiple and plastic receptors mediate tonic GABAA receptor currents in the hippocampus. J Neurosci 25: 1001610024.

Semyanov A, Walker MC, Kullmann DM, Silver RA (2004). Tonically active GABAA receptors: modulating gain and maintaining the tone. Trends Neurosci 27: 262-269. 
Sieghart W, Speck G (2002). Subunit composition, distribution and function of GABAA receptor subtypes. Curr Top Med Chem 2: 795-816.

Staley KJ, Mody I (1992). Shunting of excitatory input to dentate gyrus granule cells by a depolarizing GABAA receptormediated postsynaptic conductance. $J$ Neurophysiol 68: 197-212.

Stell BM, Brickley SG, Tang CY, Farrant M, Mody I (2003). Neuroactive steroids reduce neuronal excitability by selectively enhancing tonic inhibition mediated by delta subunit-containing GABAA receptors. Proc Natl Acad Sci USA 100: 14439-14444.

Tornberg J, Voikar V, Savilahti H, Rauvala H, Airaksinen MS (2005). Behavioural phenotypes of hypomorphic KCC2-deficient mice. Eur J Neurosci 21: 1327-1337.

Wallner M, Hanchar HJ, Olsen RW (2003). Ethanol enhances alpha 4 beta 3 delta and alpha 6 beta 3 delta gamma-aminobutyric acid type A receptors at low concentrations known to affect humans. Proc Natl Acad Sci USA 100: 15218-15223.
Wallner M, Hanchar HJ, Olsen RW (2006). Low-dose alcohol actions on $\alpha 4 \beta 3 \delta \mathrm{GABA}_{\mathrm{A}}$ receptors are reversed by the behavioral alcohol antagonist Ro15-4513. Proc Natl Acad Sci USA 103: 8540-8545.

Wei W, Faria LC, Mody I (2004). Low ethanol concentrations selectively augment the tonic inhibition mediated by delta subunit-containing GABAA receptors in hippocampal neurons. J Neurosci 24: 8379-8382.

Wohlfarth KM, Bianchi MT, Macdonald RL (2002). Enhanced neurosteroid potentiation of ternary GABAA receptors containing the delta subunit. J Neurosci 22: 1541-1549.

Woo NS, Lu JM, England R, McClellan R, Dufour S, Mount DB et al (2002). Hyperexcitability and epilepsy associated with disruption of the mouse neuronal-specific $\mathrm{K}-\mathrm{Cl}$ cotransporter gene. Hippocampus 12: 258-268.

Zhu L, Lovinger D, Delpire E (2005). Cortical neurons lacking KCC2 expression show impaired regulation of intracellular chloride. J Neurophysiol 93: 1557-1568. 